Article

\title{
An Integrated Model to Explain How Corporate Social Responsibility Affects Corporate Financial Performance
}

\section{Chin-Shien Lin ${ }^{1}$, Ruei-Yuan Chang ${ }^{2}$ and Van Thac Dang ${ }^{1, *}$}

1 Department of Business Administration, National Chung Hsing University, 250 Kuo-Kuang Rd., Taichung 402, Taiwan; E-Mail: csvincentlin@dragon.nchu.edu.tw

2 Department of Hospitality Management, Ming Dao University, 250 Kuo-Kuang Rd., Taichung 402, Taiwan; E-Mail: chang610509@gmail.com

* Author to whom correspondence should be addressed; E-Mail: wilsondang1005@gmail.com; Tel.: +886-422-840-571 (ext. 205); Fax: +886-422-858-040.

Academic Editor: Giuseppe Ioppolo

Received: 16 April 2015 / Accepted: 23 June 2015 / Published: 29 June 2015

\begin{abstract}
The effect of corporate social responsibility (CSR) on financial performance has important implications for enterprises, communities, and countries, and the significance of this issue cannot be ignored. Therefore, this paper proposes an integrated model to explain the influence of CSR on financial performance with intellectual capital as a mediator and industry type as a moderator. Empirical results indicate that intellectual capital mediates the relationship between CSR and financial performance, and industry type moderates the direct influence of CSR on financial performance. Such results have critical implications for both academia and practice.
\end{abstract}

Keywords: corporate social responsibility; intellectual capital; industry types; financial performance; structural equation modeling

\section{Introduction}

The influence of corporate social responsibility (CSR) on the financial performance of firms will determine their efforts to invest in socially responsible activities. If the influence is positive, with the goal of profit maximization, then the firms will allocate more resources to socially responsible programs to achieve better financial performance. Otherwise, if CSR activities induce negative effects, then firms may adopt a conservative attitude and be more cautious about CSR issues. Therefore, clarifying 
the relationship between CSR and financial performance is critically meaningful for the promotion of CSR implementation in any business firm, community, and country as well as in the world.

Unfortunately, contradictory standpoints of previous academic research on this issue have existed for quite a long time. Neo-classical economists considered that over-investing in CSR activities would reduce the opportunities for exploiting the resources to maximize profit [1]. Engaging in CSR activities will increase costs, trigger conflicts of interest among stakeholders [2], and thus induce competitive disadvantages and finally hurt company performance [3].

By contrast, based on the stakeholder theory perspective, investment in CSR activities can improve the relationship between firms and their stakeholders, and can help the firms secure their critical resources controlled by stakeholders [4-6]. Moreover, based on the resource-based view (RBV) [7], a firm's resources are valuable, rare, imitable, and non-substitutable. Such resources allow the firm to engage in various activities [8]. If these resources are allocated to CSR activities, then such activities will improve the brand image and public reputation of firms $[9,10]$, increase their appeal to employees, enhance customer trust [11,12], and consequently boost competitive advantages and improve the firm's financial performance [13].

Consistent with the theoretical viewpoints in the previous literature, the empirical results of prior studies also demonstrated inconclusive and mixed results. Some scholars revealed that CSR has positive effects on the financial performance of firms, whereas others reported a negative association between CSR and financial performance [9,14,15]. After reviewing 18 papers of previous CSR literature, Margolis and Walsh [14] determined that only 53\% of these papers showed a positive relationship between CSR and financial performance, implying the unidentified and confused relationship between these two variables [16].

To explain the contradictory theoretical viewpoints and inconsistent empirical results in the literature, some researchers have attempted to include other variables, such as advertising expenses, R \& D expenses [17], industry growth rate [18], and stakeholders' moral values [19], into the model, whereas other studies have further explored the inverse effect of financial performance on CSR [16]. However, an integrated model explaining the mechanism of both a mediator and a moderator has been excluded from the relationship between CSR and firm performance.

In this research, we proposed an integrated model, which includes intellectual capital as a mediator and industry type as a moderator into the relationship between CSR and financial performance. CSR is believed to improve intellectual capital, which will consequently enhance financial performance. In addition to the indirect effects on financial performance through intellectual capital, CSR also has a direct effect on financial performance, and this direct effect can be further moderated by industry type.

This paper has several contributions. First, based on RBV, the mediating model suggests that CSR will enhance intellectual capital and consequently improve financial performance, which has not been tested before. Second, several studies have examined industry as an important factor that affects CSR. For example, some scholars such as Halme and Huse, Jenkins and Yakovleva, and Line et al. [20-22] analyzed the effect of industry variations on corporate environmental disclosure. Cheung et al. [23] investigated the effect of firm valuation on corporate social performance in the service and non-service sector industries of major Hong Kong listed firms. However, none of these studies included industry type as a moderator into the relationship between CSR and firm financial performance. With these two viewpoints, this integrated model aims to propose a delicate relationship among CSR, intellectual 
capital, industry type, and financial performance to explain how CSR affects financial performance. In addition to explaining the inconsistency among previous empirical results, several empirical implications are derived from the results. The rest of the study is organized into sections. The next and second section reviews the previous literature and develops the hypotheses. The third section describes the data collection and methodology. The fourth section presents the empirical results. The final section discusses the findings and conclusions.

\section{Literature Review}

\subsection{Corporate Social Responsibility (CSR)}

Discussions on CSR issues have received considerable attention from academic researchers and practitioners for many decades. At the early stage, Chamberlain [24] defined CSR as actions that the leadership in business is expected to undertake in response to a given situation as matters of right, whether legal or illegal. CSR can only be satisfied by the performance of obligations to particular individuals and not to society as a whole. By contrast, Frederick [25] viewed CSR as a requirement for business to oversee the operation of an economic system that fulfills the expectations of the public. The means of production of firms should be employed in such a way that production and distribution would enhance the total socioeconomic welfare. However, other scholars defined CSR as a more integral concept. Carrol [26] described corporate social performance as the three-dimensional integration of CSR, corporate social responsiveness, and social issues. The author suggested that CSR should address the entire range of obligations of business to society and must encompass the economic, legal, ethical, and discretionary categories of business performance. Matten and Moon [27] also considered corporate social performance as a synonym of CSR, corporate social responsiveness, or any other interaction between business and social environment. CSR incorporates economic responsibility, public responsibility, and social responsiveness. In sum, defining CSR is difficult because the concept is a broad and complex phenomenon [26]. To sum up the notion of CSR in the previous literature, the core concept of CSR is to reflect the entire obligation of a company to its internal stakeholders, including stockholders, employees, and external stakeholders, such as customers, suppliers, and community [28].

\subsection{Benefits of CSR on Performance}

With the gradually increasing consciousness about environmental protection and social responsibility, the problem of whether investment in CSR results in a competitive advantage for a company has become a major issue for both academia and practice. Hart [29] proposed a natural RBV that considers challenges from the environment that will inevitably compel a company to develop its intangible resources, which will be a source of competitive advantage. This viewpoint is further emphasized by a similar proposition advocated by Sharma and Vredenburg [30]. These standpoints somehow assume that intellectual capital mediates the relationship between CSR and financial performance, but it has not been tested empirically.

According to the concepts underlying CSR, a company must provide products and services that are not harmful to the environment. To produce high-quality and attractive environmentally friendly products, a company may have no choice but to adopt a new technology, which may consequently 
induce product differentiations and improve financial performance [17,31]. Similarly, a company's internal process may be enhanced as a result of this improvement activity. For example, one company may need to reduce its pollution emissions to the environment by saving materials and energy [32]. However, it needs to redesign its production process, and consequently may enhance production efficiency and reduce production costs [33]. Moreover, CSR can stimulate the accumulation of human capital. Generally, a company with a high level of CSR tends to be more attractive to employees and has a low turnover rate of new employees, thus decreasing the recruitment and employee training costs [34].

By contrast, based on the viewpoint of stakeholder theory, surviving in a social environment, obtaining legitimacy, and securing critical resources require a company to exert considerable effort to build and maintain relationships with its stakeholders [6]. A good relationship with stakeholders will positively affect financial performance in the long term [35]. For example, building a new factory is easier for a company with a good relationship with stakeholders and acceptance of the community where the factory is built, reducing the costs as a result of government regulations, or even attaining tax breaks from the government [36]. A good social agenda can also build a good reputation, such that it provides a buffer to problems that are invisible or offers more opportunities for companies with CSR than companies without CSR [37].

\subsection{Negative Effects of CSR on Performance}

Several scholars suggested that CSR activities have negative effects on firm performance [38]. They argued that investment in any CSR activity will incur higher costs, inducing competitive disadvantages for companies in a competitive market. Therefore, companies with CSR will incur higher costs and less competitive advantage than those without CSR [3,39].

According to private costs theory, companies that engage in CSR activities may benefit some stakeholders. However, the amount spent on those CSR activities may not be covered by the benefits generated. These CSR activities even disperse a company's objective from profit maximization, and thus negatively affect firm financial performance [40-42]. Furthermore, managerial guile theory [39] also states that monitoring the behavior of managers is difficult for stockholders, particularly in a large company. Investing in CSR activities is occasionally aimed at the self-interest of managers. Similar to the viewpoint of private costs theory, the amount spent on those CSR activities may not be covered by the benefits generated; consequently, CSR activities will negatively affect firm financial performance [43].

\subsection{Intellectual Capital}

Intellectual capital is one of the most important intangible resources for creating value for a company [44,45]. According to Brooking [46], intellectual capital is the combination of intangible assets, which enables the company to function. Stewart [47] defined intellectual capital as "packaged useful knowledge." Similarly, Edvinsson and Malone [48] described intellectual capital as "intellectual materials that can be converted into values". Zeghal and Maaloul [49] also defined intellectual capital as the sum of all types of knowledge a company uses to conduct business, ultimately creating value for the company. Some of elements of intellectual capital include human capital, structural capital, and customer capital [50]. Human capital refers to employee competences, knowledge, skills, and all aspects of human resources. Structural capital pertains to elements, such as software systems, supply 
chains, and corporate flows. Customer capital denotes customers, customer loyalty, customer relationship, distribution channels, good contracts, and licenses [51].

The rapid progress of technology development has spurred the new knowledge economy, changing the way a company earns its profits. In other words, the profit-generating paradigm has changed from production orientation to marketing orientation, and subsequently from marketing orientation to the current knowledge orientation. The role of intellectual capital has become increasingly important in creating competitive advantage and business value for a company. Consequently, a growing number of researchers have examined the issues of intellectual capital [51,52].

\subsection{Industry Effect}

CSR disclosure varies across industries because of the various costs and benefits associated with diverse industry characteristics [53,54]. For instance, Harte and Owen [55] indicated that industry sensitivity to the environment will affect the social responsibility disclosure of firms. Environmentally sensitive firms are more likely to disclose their environmental performance [53,54]. Companies with manufacturing processes that negatively influence the environment will have more disclosure compared with companies in other industries. In general, industries including mining, petroleum, and chemical companies will emphasize the environment, health, and safety [21,22], and firms in the finance and service industries will disclose behaviors related to social issues and donations [22]. The empirical results of numerous studies have demonstrated that the mining, resource, paper and pulp, electric power, water resource, as well as chemical and medical industries significantly influence the environment [56,57]. Other industries, particularly new manufacturing and service industries, do not influence the environment as much as those companies do. Therefore, they will have less disclosure on environmental issues. The companies in these industries will have fewer expectations regarding environmental performance, and thus have less disclosure [56,57].

\section{Conceptual Model and Hypotheses Development}

To understand the relationship between CSR and firm financial performance, we propose an integrated model that integrates intellectual capital as a mediator and industry type as a moderator into the relationship between CSR and firm financial performance. In this model, we argue that CSR is significantly associated with firm financial performance (H1), and CSR can also enhance firms' intellectual capital (H2), which in turn increases firm financial performance (H3). In other words, intellectual capital will mediate the relationship between CSR and firm financial performance (H4). We also argue that industry type will moderate the relationship between CSR and firm financial performance (H5) (as illustrated in Figure 1). In the subsequent section, the relationship between variables and the theoretical support for the hypotheses is established. 


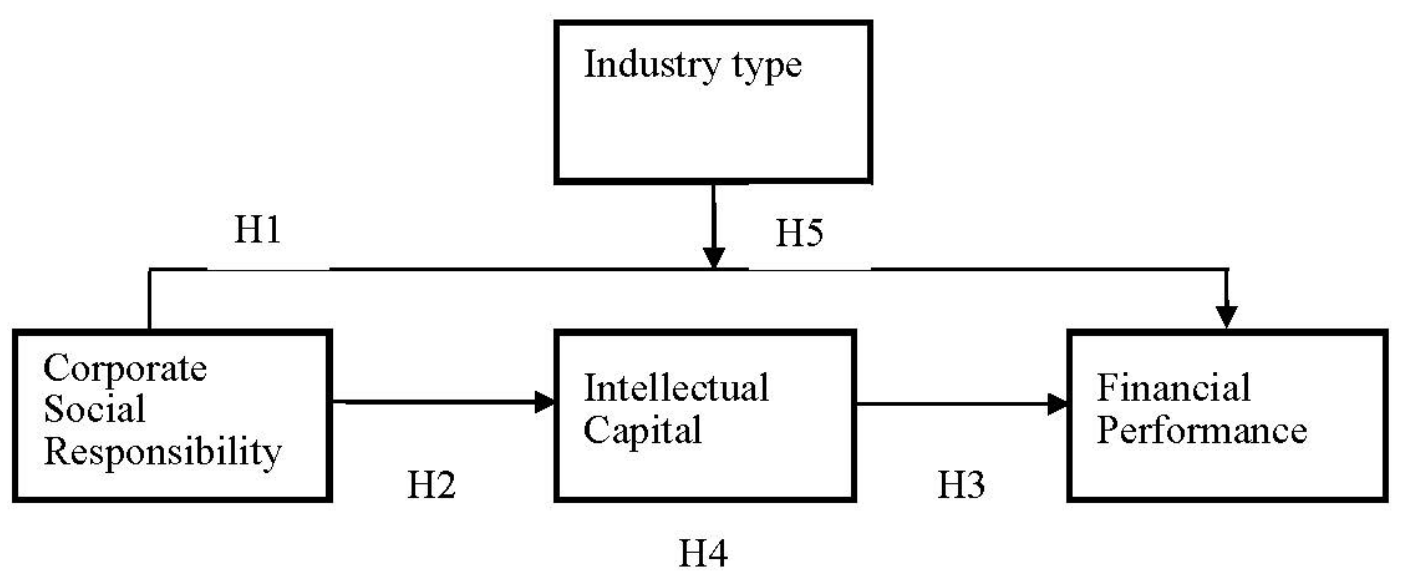

Figure 1. Research framework.

\subsection{Relationship between CSR and Firm Financial Performance}

According to Barnett [2], and Shen and Chang [3], a firm's investment in CSR generally does not benefit a firm and its shareholders. CSR activities, such as establishing relationships with employees and the community, protecting the environment, and improving corporate governance, will increase a firm's costs because of a shift in focus from the maximization of shareholder value to the advancement of the interests of a wider set of stakeholders. By contrast, many other studies revealed that CSR is positively associated with corporate performance $[12,42]$. CSR contributes to the development of a favorable company image [58], enabling the firm to secure critical resources [37], enhance product competitiveness [37], and boost employee productivity [11]. Although a consistent conclusion on the effect of CSR on firm performance has been lacking in previous literature, these studies provided ample evidence on the direct relationship between CSR and firm performance. Thus, we posit the first hypothesis as follows:

Hypothesis 1: A direct relationship exists between CSR and firm financial performance.

\subsection{Relationship between CSR and Intellectual Capital}

According to RBV, a company needs to develop valuable, rare, imitable, and non-substitutable resources to create competitive advantages [7]. Hart [29] claimed that companies may be compelled to purchase new machinery or equipment to ensure that the production process is responsive to environmental protection requirements from the community and government, and that the firms are capable of providing environmentally friendly products, which may create process capital. Similarly, a company may have to improve its corporate governance and management system to foster a good relationship with employees, attract more excellent employees, and ultimately create human capital. Moreover, to provide environmentally friendly products, a company may nurture an innovation culture to develop new products and services, consequently increasing a company's innovation capital and building a green corporate culture. Companies may be better recognized by consumers who will be more willing to pay higher prices for products and services sold by these companies because of their investment in CSR activities. CSR activities help firms establish and maintain a good relationship with customers, 
hence creating customer capital. With all of these CSR-related investments, companies can generate more intellectual capital. Therefore, we propose the second hypothesis as follows:

Hypothesis 2: A positive relationship exists between CSR and intellectual capital.

\subsection{Relationship between Intellectual Capital and Firm Financial Performance}

Prior studies reveal a significant relationship between a company's intellectual capital and corporate performance [12,49,59-61]. Chen et al. [62] used a questionnaire to conduct a survey on high-tech industry in Taiwan. Their results suggested that intellectual capital has a significant relationship with business performance. In a similar study, Chen et al. [59] determined the intellectual capital and business performance of Taiwanese companies. Their findings indicated that a firm's intellectual capital positively affects market value and financial performance, and intellectual capital may be an indicator for future financial performance. Tan et al. [61] further investigated a firm's intellectual capital and performance and reported that intellectual capital is positively correlated to future company performance, and the growth rate of a company's intellectual capital is positively related to the firm's performance.

Intellectual capital is one of the most important intangible resources in producing company value $[44,45]$. It can create a company-based capability that can enhance values for a company in various fields, which cannot be depleted with use, cannot be replaced, and is difficult to imitate $[52,63]$. Other researchers also pointed out that the value of a company is a function of the investment in intellectual capital [64]. Some researchers concluded that compared with other resources, intellectual capital is one of the major sources of competitive advantage [51]. Based on the findings and arguments of prior researchers, we propose the third hypothesis as follows:

Hypothesis 3: A positive relationship exists between intellectual capital and firm financial performance.

The preceding discussion indicated that solely examining the direct link from CSR to firm performance will generate inconsistent and mixed results. However, investment in CSR activities will have not only a direct effect on firm performance, but also an indirect effect through several mediating variables because of the nature underlying the CSR concept [17,19]. This result implies that the link between CSR and firm performance will be mediated by some other variables [16]. Based on these arguments $[16,17,19]$ and from the developed hypotheses, we argue that a company that invests in CSR activities will improve the intellectual capital of a firm, which consequently increases its performance. Therefore, we posit the fourth hypothesis as follows:

Hypothesis 4: Intellectual capital will mediate the relationship between CSR and corporate performance.

\subsection{Moderating Role of Industry Type}

According to Bitektine and Haack [4], the growth and success of an organization depend on its relationship with several actors or stakeholders (e.g., employees, shareholders, consumers, suppliers, government agencies, etc.) in internal organization and external society. As CSR issues become increasingly important in the current business environment, organizations must invest considerable efforts and resources in CSR activities to satisfy stakeholder requirements and to obtain legitimacy and the resources controlled by these stakeholders. For example, consumers demand highly environmentally 
friendly products and services, a legal agency requires companies to adopt a non-toxic and low $\mathrm{CO}_{2}$ emission production process, the local community expects companies to provide more philanthropic funds to society, or shareholders require companies to improve corporate governance to secure their investments. Such forces from stakeholders motivate firms to engage in a variety of CSR activities [19]. However, depending on the intensity level of these forces in various industries, firms will respond to CSR issues in different ways, generating diverse consequences. In environmentally sensitive industries with serious requirements of non-toxic packaging, low pollution processing, non-use of sweatshop labor manufacturing practices, etc., from customers, the community, and government, companies with high-level CSR can satisfy the expectations of stakeholders and earn their recognition, consequently engendering a good relationship with these stakeholders as well as positive effects on financial performance. By contrast, in environmentally non-sensitive industries, the requirements of the stakeholders of companies are not as stringent as those of stakeholders in environmentally sensitive industries. Companies that engage in CSR activities will not necessarily be recognized by their stakeholders. Moreover, they will not obtain the positive evaluation of their stakeholders as CSR investments increase, and the amount of money spent on those CSR activities will lose its meaning and disperse company objectives, resulting in the negative effect of CSR on financial performance [3]. In other words, the requirements from stakeholders (e.g., consumers, suppliers, government agencies, shareholders, etc.) in environmentally sensitive industries are significantly more serious and intense than in environmentally non-sensitive industries. Companies in environmentally sensitive industries engage in CSR activities that will satisfy stakeholder requirements, and these companies will obtain reputation, recognition, and resources controlled by these stakeholders. Consequently, the companies will gain advantages and increases in financial performance. By contrast, companies in environmentally non-sensitive industries do not need to considerably invest in CSR activities because their stakeholders do not require the firms to do so. CSR activities in these firms are unnecessary. If the firms substantially invest in CSR activities, then the costs and efforts in these CSR activities will negatively affect their performance.

Furthermore, Sen and Bhattacharya [65] suggested that the costs of resources used in CSR activities vary among firms across industries. In environmentally sensitive industries, firms have to invest huge amounts of money and resources in CSR activities, such as investment in R \& D to produce green products or building production facility and waste processing systems to improve and increase the environmental performance of products and services. These CSR activities are necessary and will help firms create differentiated products and services, thus boosting their sales and financial performance [66,67]. However, in environmentally non-sensitive industries, firms do not necessarily create or improve products and services in environmental orientation. Investments in CSR activities will negatively affect the firm performance because the costs of resources used in CSR activities are extremely high [68].

Based on these arguments, we argue that industry type will moderate the relationship between CSR and the financial performance of firms. For companies in environmentally sensitive industries, more CSR activities will improve financial performance. By contrast, more CSR activities will worsen the financial performance of companies in environmentally non-sensitive industries. Therefore, we propose the fifth hypothesis as follows:

Hypothesis 5: Industry type will moderate the direct effect of CSR on financial performance. 


\section{Methodology}

\subsection{Sample and Data Collection}

The study population consisted of the 500 largest companies in the American stock market (S \& P 500). Data were collected from two sources, namely, KLD and Compustat databases. KLD or Kinder Lyndenberg Dommini rating system is an independent social science database that provides performance benchmarks, corporate accountability research, consulting services, global research, and index products to facilitate the integration of environmental, social, and governance factors. KLD social ratings consist of social index and controversial business issues. Social index is used in evaluating the social responsibility behavior of firms, which has been extensively used by several researchers [69,70].

To gather more data for analysis, data were collected from 1998 to 2008. All of the variables used in this study, including CSR, intellectual capital, financial performance, and control variables, were obtained from these two databases. After deleting the records with missing variables, the final sample data consisted of 1144 firm-year observations.

\subsection{Corporate Social Responsibility}

CSR is a complicated construct to measure because of its multi-dimensions and nature of invisibility. A considerable number of theoretical and empirical studies have measured CSR in many different ways. For example, Stanwick and Stanwick [71] used the Fortune Corporate Reputation Index to evaluate a firm's social responsibility; this index considers eight attributes, namely, quality of management, quality of products or services, innovativeness, long-term investment value, financial soundness, ability to attract, develop, and retain talented employees, wise use of corporate assets, and responsibility to the community and environment. Prior et al. [72] employed SiRi Pro ${ }^{\mathrm{TM}}$ to measure a firm's responsibilities with perspectives from the community, corporate governance, customers, employees, the environment, and vendors and contractors. Shen and Chang [3] evaluated a firm's social responsibility in terms of social participation, environmental protection, and financial transparency.

Despite the unavailability of a census in measuring CSR, using KLD indexes to evaluate CSR has gradually become an international standard. KLD measures CSR with numerous dimensions, including community impact, corporate governance, human rights, diversity, employee relationships, environmental impact, product safety, and controversial business issues. Using KLD indexes has several advantages. First, the data set is based on an extensive survey every year. Second, KLD indexes can be compared between companies and are appropriate for doing research in business ethics. Therefore, this study adopts KLD indexes to measure CSR.

\subsection{Intellectual Capital}

According to the Austrian approach in intellectual capital theory [49,61,73-75], intellectual capital is a multidimensional construct that can be measured using the VAICTM model. Pulic [73] concluded that a company's value creation principally originates from intellectual capital and physical capital. Given that VAIC ${ }^{\text {TM }}$ method can reflect a company's value created through intellectual capital, the method has been widely adapted by numerous researchers and practitioners to measure a company's 
intellectual capital. At the same time, the validation and application of this method have been supported by several scholars [76]. Following Firer and Williams [60], Pulic [73], and Nazari and Herremans [75], we describe the following steps in computing VAICTM:

In the first step, the capacity of a company to create value added (VA) is computed as the sum of interest expenses (I), depreciation expenses (DP), dividends (D), corporate taxes (T), equity of minority shareholders in net income of subsidiaries $(\mathrm{M})$, and profits retained for the year $(\mathrm{R})[60]$ :

$$
\mathrm{VA}=\mathrm{I}+\mathrm{DP}+\mathrm{D}+\mathrm{T}+\mathrm{M}+\mathrm{R}
$$

In the second step, the value added human capital coefficient (VAHU) is calculated. VAHU represents the relationship between value added and company human capital (HU). Human capital indicates the individual knowledge stock of an organization as represented by its employees [51]. It includes employee skills, competence, attitudes, and all of the behavioral components of the employees' work [73]. HU generates value through investments to increase the knowledge, skills, talents, and know-how of individuals [51]. Therefore, employee costs are used as an indicator of HU [75]. The calculation of VAHU is as follows:

$$
\mathrm{VAHU}=\mathrm{VA} / \mathrm{HU}
$$

where VAHU is the value added HU coefficient, and HU is measured by labor and related employee costs.

The relationship between VA and structural capital (SC) is captured by the value added structural capital coefficient (VASC), representing VA created by company structural capital. VASC is computed as the ratio of $\mathrm{SC}$ to $\mathrm{VA}$.

$$
\mathrm{VASC}=\mathrm{SC} / \mathrm{VA}
$$

where VASC is the value added SC coefficient, and SC is the structural capital.

From Equation (3), the denominator is VA and the numerator is SC, whose implication is different from that of Equation (2). The basic logic is that intellectual capital primarily consists of $\mathrm{HU}$ and SC $[49,61,73,74]$. Therefore, HU and SC are negatively correlated in a company's value creation. The greater the contribution of $\mathrm{HU}$ in value creation, the lesser is the contribution of SC, and vice versa. SC is computed as follows:

$$
\mathrm{SC}=\mathrm{VA} / \mathrm{HU}
$$

The next step is to calculate the contribution of physical capital (CA) employed in value creation. Value added capital coefficient (VACA) indicates how much value has been created by one unit invested in capital employed.

$$
\mathrm{VACA}=\mathrm{VA} / \mathrm{CA}
$$

where CA is measured by the book value of net assets.

Finally, VAIC ${ }^{\text {TM }}$ is calculated by adding VAHU, VASC, and VACA.

$$
\mathrm{VAIC}=\mathrm{VAHU}+\mathrm{VASC}+\mathrm{VACA}
$$

The value of VAICTM represents the value created by a company's total resource, which can be divided into three components, namely, HU, SC, and CA. In this research, the sum of VAHU and VASC is used as the proxy of intellectual capital for our analysis. All of the data for the intellectual 
capital calculation were obtained from the 500 largest companies in the American stock market (S\&P 500) in the Compustat database.

\subsection{Financial Performance}

The financial performance indicators used in the previous literature can be roughly divided into market- and accounting-based measures. Market-based measures such as Tobin Q and market value are calculated based on the market value from the viewpoints of investors on a specific date. Accounting-based measures are calculated based on the performance derived within a time interval, such as earnings per share (EPS), return on assets (ROA), and return on equity (ROE). McWilliams and Siegel [17] suggested that in contrast to market-based measures, accounting-based measures such as ROA and ROE can reflect a company's internal decision-making process and managers' performance. In addition, Moore [77] indicated that determining the relationship between CSR and financial performance using accounting-based instead of market-based measures is more appropriate in terms of the detection purpose, particularly ROA. Therefore, the current study adopted ROA measure, which is calculated as the ratio between profits before tax to total assets. However, a disadvantage of ROA is its variation between industries; thus, the standardized scores of ROA are used as the proxy for financial performance.

\subsection{Industry Type}

According to Bansal and Clelland [78], Sealy et al. [79], and Polosky and Zeffane [80], environmentally sensitive industries consist of companies that could gravely damage the environment during the production process. The companies in these industries are classified by the World Commission on Environment and Development [81] as oil, gas, chemicals, utilities, paper and pulp, and electric utilities companies. By contrast, environmentally non-sensitive industries (i.e., pharmaceutical, food, beverage, etc.) consist of companies that could not substantially damage the environment during the production process [68,78,82]. Based on the classification of the World Commission on Environment and Development [81] and prior studies [68,78-80,82], we used the four-digit SIC of $500 \mathrm{~S} \& \mathrm{P}$ companies in the Compustat database to divide all companies into environmentally sensitive and non-sensitive industries.

\subsection{Control Variables}

Variables that may affect the financial performance are controlled during the analysis process to elicit the net effects of CSR and financial performance. These variables have been extensively used in previous studies and have confirmed the potential influence on firm performance, including the natural logarithm of the number of employees to reflect firm size [83], ratio of total assets to total sales to represent capital intensity $[18,83]$, and the ratio of $\mathrm{R} \& \mathrm{D}$ expenses to total assets to reflect a firm's R\&D intensity $[83,84]$. 


\subsection{Analysis Methods}

In this study, regression analysis was used to test the hypotheses. First, the mediation hypothesis of intellectual capital on the relationship between CSR and financial performance was tested based on the method proposed by Baron and Kenney [85]:

$$
\begin{array}{r}
R O A=\theta_{0}+\theta_{1} \text { FimSize }+\theta_{2} \text { Capital Intensity }+\theta_{3} R \& D \text { Intensity }+\theta_{4} C S R+\epsilon_{1} \\
I C=\beta_{0}+\beta_{1} \text { FirmSize }+\beta_{2} \text { Capital Intensity }+\beta_{3} R \& D \text { Intensity }++\beta_{4} C S R+\epsilon_{2} \\
R O A=\delta_{0}+\delta_{1} \text { FirmSize }+\delta_{2} \text { Capital Intensity }+\delta_{3} R \& D \text { Intensity }+\delta_{4} I C+\delta_{5} C S R+\epsilon_{3}
\end{array}
$$

According to Baron and Kenney [85], the following conditions must hold to establish mediation: (1) CSR must affect financial performance (ROA) in the first model; (2) CSR must affect intellectual capital (IC) in the second model; and (3) when ROA is regressed on both CSR and IC in the third model. IC must affect financial performance. If the effect of CSR on financial performance is less in the third model than in the first model, then partial mediation holds. Perfect mediation holds if CSR has no effect on financial performance in the third model.

Baron and Kenny [85] and Kutner et al. [86] identified subgroup analysis as a method for testing the moderation effect. This method is often used to test the strength of moderation [87]. A sample is split into groups based on the moderator variable. The relationship between the predictor and the response variable is subsequently tested across different groups of the moderator. Therefore, to test the moderating effect of industry type on the relationship between CSR and financial performance, we divided the sample data into two groups (environmentally sensitive and environmentally non-sensitive industries). The effect of CSR on financial performance was subsequently tested across different groups. The following regression equation was used to test the effect of CSR on financial performance between environmentally sensitive industries and environmentally non-sensitive industries:

$$
R O A=\theta_{0}+\theta_{1} \text { FimSize }+\theta_{2} \text { Capital Intensity }+\theta_{3} R \& D \text { Intensity }+\theta_{4} C S R+\epsilon_{1}
$$

\section{Empirical Results}

\subsection{Descriptive Statistics and Correlation Matrix}

Table 1 presents the descriptive statistics of all of the variables used in this study. In addition to the correlation coefficients between all of the variables, the means and standard deviations of each variable are shown in the first and second columns, respectively. CSR is significantly and positively related to IC $(r=0.331, p<0.01)$, implying that as the level of CSR increases, the value of IC grows. IC is also significantly and positively related to financial performance $(r=0.072, p<0.01)$, implying that as the level of IC increases, its financial performance improves. 
Table 1. Correlation matrix, means, and standard deviations.

\begin{tabular}{lcccccccc}
\hline & Mean & SD & $\mathbf{1}$ & $\mathbf{2}$ & $\mathbf{3}$ & $\mathbf{4}$ & $\mathbf{5}$ & $\mathbf{6}$ \\
\hline 1. Firm Size & 1.327 & 0.016 & 1.000 & & & & & \\
2. Capital Intensity & 1.273 & 0.027 & $-0.293^{* *}$ & 1.000 & & & & \\
3. R\&D Intensity & 0.299 & 0.018 & -0.036 & $0.208 * *$ & 1.000 & & & \\
4. Corporate Social Responsibility & 1.233 & 0.028 & $0.447^{* *}$ & -0.001 & -0.009 & 1.000 & & \\
5. Intellectual Capital & 0.585 & 0.042 & $0.301 * *$ & 0.062 & 0.020 & $0.331 * *$ & 1.000 & \\
6. ROA & 0.063 & 0.004 & $0.070^{* *}$ & $-0.152 * *$ & -0.021 & -0.017 & $0.072 * *$ & 1.000 \\
\hline
\end{tabular}

Note: $n=1144,{ }^{*} p<0.05, * * p<0.01, * * * p<0.001$ Return on assets (ROA).

\subsection{Hypotheses Testing}

Table 2 presents the regression results for testing the mediating effect of IC in the relationship between CSR and firm financial performance. As indicated in model 1, CSR is significantly and positively related to firm financial performance $(\beta=0.266, p<0.001)$, supporting hypothesis 1 . In model 2, CSR is also significantly and positively related to IC ( $\beta=0.092, p<0.05)$, supporting hypothesis 2 . In model 3, both CSR and IC are included in the regression model, and the results indicate that IC is significantly and positively related to firm financial performance $(\beta=0.167, p<0.001)$, supporting hypothesis 3 . The results also indicate that the effect of CSR on firm financial performance is significant and positive in model $3(\beta=0.141, p<0.01)$. However, the regression coefficient of CSR $(\beta=0.141)$ in model 3 is less than that in model $1(\beta=0.266)$, indicating that IC partly mediates the relationship between CSR and firm financial performance. Thus, hypothesis 4 is also supported.

Table 2. Regression results for the mediating effect of intellectual capital (IC).

\begin{tabular}{lccc}
\hline & Model 1 (ROA) & Model 2 (Intellectual Capital) & Model 3 (ROA) \\
\hline Constant & $0.11 * * *$ & $-19.9 * * *$ & $0.12 * * *$ \\
Control variables & & & \\
$\quad$ Firm Size & $-0.152 * *$ & $0.302 * * *$ & $-0.202 * * *$ \\
$\quad$ Capital Intensity & $-0.256 * * *$ & $0.220 * * *$ & $-0.293 * * *$ \\
$\quad$ R\&D Intensity & 0.035 & 0.049 & 0.027 \\
Explanatory variables & & & \\
$\quad$ Corporate social responsibility & $0.266 * * *$ & $0.092 *$ & $0.141 * *$ \\
$\quad$ Intellectual capital & & & $0.167 * * *$ \\
$R^{2}$ & 0.380 & 0.667 & 0.441 \\
Adjusted $R^{2}$ & 0.304 & 0.585 & 0.382 \\
F test & $8.220 * * *$ & $22.451 * * *$ & $9.213 * * *$ \\
\hline
\end{tabular}

Note: $n=1144, * p<0.05, * * p<0.01, * * * p<0.001$. Return on assets (ROA).

To test the moderating effect of industry type on the relationship between CSR and firm financial performance, financial performance is regressed on CSR for each data set (environmentally sensitive and environmentally non-sensitive industries). For those companies classified into the environmentally sensitive industries, CSR is significantly and positively related to financial performance $(\beta=0.186$, $p<0.001$ ), as shown in Table 3. However, for those companies classified in environmentally non-sensitive industries, CSR is significantly and negatively related to financial performance 
$(\beta=-0.107, p<0.01)$. Thus, the effect of CSR on firm financial performance is different between environmentally sensitive and environmentally non-sensitive industries, supporting hypothesis 5 .

Furthermore, to recheck the moderating effect of industry type on the relationship between CSR and firm financial performance, firm financial performance is regressed on the interaction effect between CSR and industry type. The slope of the intersection term is significantly negative $(\beta=-0.110$, $p<0.001$ ), indicating that the effect of CSR on financial performance in environmentally sensitive industries is more than that in non-environmentally sensitive industries by 0.11 , as shown in Table 4 . This result suggests that industry type is a factor that moderates the relationship between CSR and firm financial performance.

Table 3. Regression results for the moderating effect of industry type.

\begin{tabular}{lcc}
\hline & Model 1 (Sensitive Industry) & Model 2 (Non-Sensitive Industry) \\
\hline Constant & $0.114 * * *$ & $0.064 * * *$ \\
Control variables & & \\
$\quad$ Firm Size & $-0.152 * *$ & $0.099 * *$ \\
$\quad$ Capital Intensity & $-0.256^{* * *}$ & $-0.116^{* *}$ \\
$\quad$ R\&D Intensity & 0.035 & 0.001 \\
Explanatory variable & & \\
$\quad$ Corporate social responsibility & $0.186 * * *$ & $-0.107 * *$ \\
$R^{2}$ & 0.330 & 0.267 \\
Adjusted $R^{2}$ & 0.274 & 0.206 \\
F test & $5.320 * * *$ & $4.551 * * *$ \\
\hline
\end{tabular}

$* p<0.05,{ }^{* *} p<0.01,{ }^{* * *} p<0.001$. Return on assets (ROA).

Table 4. Regression results for total sample with and without the interaction term.

\begin{tabular}{lcc}
\hline & Model 1 (ROA) & Model 2 (ROA) \\
\hline Constant & $0.079 * * *$ & $0.079 * * *$ \\
Control variables & & \\
$\quad$ Firm Size & 0.046 & 0.056 \\
$\quad$ Capital Intensity & $-0.141 * * *$ & $-0.139 * * *$ \\
$\quad R$ \& D Intensity & 0.008 & 0.005 \\
Explanatory variable & & \\
$\quad$ Corporate social responsibility & -0.039 & 0.011 \\
$\quad$ Corporate social responsibility ${ }^{*}$ Industry Type & & $-0.110 * * *$ \\
$R^{2}$ & 0.160 & 0.267 \\
Adjusted $R^{2}$ & 0.132 & 0.206 \\
$F$ test & $6.220 * * *$ & $4.551 * * *$ \\
\hline \multicolumn{2}{l}{$* 0.05, * * p<0.01, * * * p<0.001$. Return on assets (ROA). }
\end{tabular}

\section{Conclusions and Suggestions}

The inconsistent and mixed findings on the effects of CSR on the financial performance of firms signify a critical gap in the previous literature. To fill in this gap, this study proposed an integrated model to explain how CSR affects financial performance with the mediating role of intellectual capital and the moderating role of industry type. Based on RBV, efforts invested in CSR activities can increase 
intellectual capital, which consequently induces positive effects on financial performance. Moreover, based on stakeholder theory, firms have to engage in a variety of CSR activities to satisfy stakeholder expectations because of the requirements regarding the CSR issues of stakeholders (e.g., customers, suppliers, employees, shareholders, community, government agency, etc.). However, stakeholder requirements have different levels of intensity in various industries. The forces from stakeholders are often more serious and intensive in environmentally sensitive industries than in environmentally non-sensitive industries. Companies in environmentally sensitive industries obtain more recognition and resources from stakeholders as they invest more in CSR. However, for companies in environmentally non-sensitive industries, investment in CSR does not necessarily result in the recognition and positive evaluation of their stakeholders. Thus, the effect of CSR on firm financial performance varies with different industry types.

The empirical results indicate that CSR can indeed enhance intellectual capital, which can increase financial performance. However, the direct effect of CSR on financial performance varies within different industry types. This direct effect is significantly positive in environmentally sensitive industries, but significantly negative in environmentally non-sensitive industries. In other words, for companies in environmentally sensitive industries, CSR activities can enhance IC, and thus improve financial performance. Although CSR activities can enhance IC and improve financial performance, investment in CSR activities may not earn the recognition and positive evaluation from the stakeholders of companies in environmentally non-sensitive industries, consequently inducing a negative effect on financial performance. These empirical results suggest important strategic actions for practitioners.

Although the empirical results indicate that CSR positively affects financial performance in environmentally sensitive industries and negatively affects financial performance in environmentally non-sensitive industries, the drastic climate change has increased disasters all over the world. The methods of business that sacrifice social welfare for profit maximization are gradually becoming unacceptable. People are imposing increased pressure on companies for a higher level of CSR. Therefore, along with this trend, the definitions of whether a company is classified as environmentally sensitive or environmentally non-sensitive will also change. As the CSR requirements increase, the direct effect of CSR on financial performance will be significantly positive for all industry types. The direct effect of CSR on financial performance will become obviously positive only after CSR reaches a certain level, and this effect can be further pursued in future research.

Different theories and viewpoints have been proposed to explain the relationship between CSR and financial performance in the past, and inconsistent and mixed empirical results have emerged, implying the complex relationship between CSR and financial performance. Discussing only the direct effect of CSR on financial performance will not engender a clear understanding of this relationship. The problem is that several other mediator and/or moderator variables may play an important role in the relationship between CSR and financial performance. Although this study proposed an integrated model with the mediating role of intellectual capital and a moderating role of industry type, many other variables exist that will mediate and/or moderate this relationship. Further research should examine other possible variables to enhance the understanding of the effects of CSR on financial performance.

Finally, the construct of IC used in this study was measured as a single construct. The measurement of CSR was also a single overall KLD index. Future research can divide CSR and IC capital constructs further into sub-elements to investigate a detailed relationship between each activity of CSR and IC 
elements and financial performance. Such study will provide further detailed decision implications for managers.

\section{Author Contributions}

The paper was conducted by Chin-Shien Lin, Ruei-Yuan Chang and Van Thac Dang. Chin-Shien Lin contributed to research ideas, instruction and decision making aspects of this paper. Ruei-Yuan Chang contributed to data collection, variables measurement and writing complementation. Van Thac Dang contributed to writing and detailed revision of this paper. All authors have read and approved the final manuscript. First author: Chin-Shien Lin. Second author: Ruei-Yuan Chang. Third author (corresponding author): Van Thac Dang.

\section{Conflicts of Interest}

The authors declare no conflict of interest

\section{References}

1. Friedman, M. A friedman doctrine: The social responsibility of business is to increase its profits. The New York Times Magazine, 13 September 1970.

2. Barnett, M. Stakeholder influence capacity and the variability of financial returns to corporate social responsibility. Acad. Manag. Rev. Arch. 2007, 32, 794-816.

3. Shen, C.H.; Chang, Y. Ambition versus conscience, does corporate social responsibility pay off? The application of matching methods. J. Bus. Ethics 2009, 88, 133-153.

4. Bitecktine, A.; Haack, P. The macro and micro of legitimacy: Toward a multilevel theory of the legitimacy process. Acad. Manag. Rev. 2015, 40, 49-75.

5. Tu, J.C.; Huang, H.S. Analysis on the relationship between green accounting and green design for enterprises. Sustainability 2015, 7, 6264-6277.

6. Russo, A.; Perrini, F. Investigating stakeholder theory and social capital: CSR in large firms and SMEs. J. Bus. Ethics 2010, 91, 207-221.

7. Barney, J. Firm resources and sustained competitive advantage. J. Manag. 1991, 17, 99-120.

8. Ruf, B.M.; Muralidhar, K.; Brown, R.M.; Janney, J.J.; Paul, K. An empirical investigation of the relationship between change in corporate social performance and financial performance: A stakeholder theory perspective. J. Bus. Ethics 2001, 32, 143-156.

9. Orlitzky, M.; Schmidt, F.L.; Rynes, S.L. Corporate social and financial performance: A meta-analysis. Organ. Stud. 2003, 24, 403-441.

10. Brown, T.J.; Dacin, P.A. The company and the product: Corporate associations and consumer product responses. J. Mark. 1997, 61, 68-84.

11. Greening, D.W.; Turban, D.B. Corporate social performance as a competitive advantage in attracting a quality workforce. Bus. Soc. 2000, 39, 254-280.

12. Wang, Q.; Wong, T.J.; Xia, L. State ownership, the institutional environment, and auditor choice: Evidence from china. J. Account. Econ. 2008, 46, 112-134. 
13. Bird, R.; Hall, A.; Momente, F.; Reggiani, F. What Corporate Responsibility Activities Are Valued By the Market? J. Bus. Ethics 2007, 76, 189-206.

14. Margolis, J.D.; Walsh, J.P. People and Profits? The Search for a Link Between a Company's social and Financial Performance; Lawrence Erlbaum: London, UK, 2001.

15. Mahon, J.F. Corporate reputation: A research agenda using strategy and stakeholder literature. Bus. Soc. 2002, 41, 415-445.

16. Surroca, J.; Tribo, J.A.; Waddock, S. Corporate responsibility and financial performance: The role of intangible resources. Strateg. Manag. J. 2010, 31, 463-490.

17. McWilliams, A.; Siegel, D. Corporate social responsibility and financial performance: Correlation or misspecification? Strateg. Manag. J. 2000, 21, 603-609.

18. Russo, M.V.; Fouts, P.A. A resource-based perspective on corporate environmental performance and profitability. Acad. Manag. J. 1997, 40, 534-559.

19. Schuler, D.A.; Cording, M. A corporate social performance-corporate financial performance behavioral model for consumers. Acad. Manag. Rev. 2006, 31, 540-558.

20. Halme, M.; Huse, M. The influence of corporate governance, industry and country factors on environmental reporting. Scand. J. Manag. 1997, 13, 137-157.

21. Jenkins, H.; Yakovleva, N. Corporate social responsibility in the mining industry: Exploring trends in social and environmental disclosure. J. Clean. Prod. 2006, 14, 271-284.

22. Line, M.; Hawley, H.; Krut, R.The development of global environmental and social reporting. Corpor. Environ. Strategy 2002, 9, 69-78.

23. Cheung, Y.L.; Jiang, K.; Mak, B.C.; Tan, W. Corporate social performance, firm evaluation, and industrial defference: Evidence from Hong Kong. J. Bus. Ethics 2013, 114, 625-631.

24. Chamberlain, N.W. The Limits of Corporate Responsibility; Basic Books: New York, NY, USA, 1973.

25. Frederick, W.C. Corporate Social Responsibility in the Reagan Era and Beyond. Calif. Manag. Rev. 1983, 25, 145-157.

26. Carroll, A.B. Corporate social responsibility: Evolution fo a definitional construct. Bus. Soc. 1999, 38, 268-295.

27. Matten, D.; Moon, J. Corporate social responsibility education in Europe. J. Bus. Ethics 2005, 54, 323-337.

28. Orlitzky, M.; Siegel, D.S.; Waldman, D.A. Strategic corporate social responsibility and environmental sustainability. Bus. Soc. 2011, 50, 6-27.

29. Hart, S.L. A natural-resource-based view of the firm. Acad. Manag. Rev. 1995, 20, 986-1014.

30. Sharma, S.; Vredenburg, H. Proactive corporate environmental strategy and the development of competitively valuable organizational capabilities. Strateg. Manag. J. 1998, 19, 729-753.

31. Berning, A.; Venter, C. Sustainable supply chain engagement in a retail environment. Sustainability 2015, 7, 6246-6263.

32. King, A.; Lenox, M. Exploring the locus of profitable pollution reduction. Manag. Sci. 2002, 48, 289-299.

33. Christmann, P. Effects of "best practices" of environmental management on cost advantage: The role of complementary assets. Acad. Manag. J. 2000, 43, 663-680.

34. Albinger, H.S.; Freeman, S.J. Corporate social performance and attractiveness as an employer to different job seeking populations. J. Bus. Ethics 2000, 28, 243-253. 
35. Brown, J.A.; Forster, W.R. CSR and stakeholder theory: A tale of Adam Smith. J. Bus. Ethics 2013, 112, 301-312.

36. Parmar, B.L.; Freeman, R.E.; Harrison, J.S.; Wicks, A.C.; Purnell, L.; Colle, S.D. State holder theory: State of the arts. Acad. Manag. Ann. 2010, 4, 403-445.

37. Fombrun, C.; Gardberg, N.; Barnett, M. Opportunity platforms and safety nets: Corporate citizenship and reputational risk. Bus. Soc. Rev. 2000, 105, 85-106.

38. Berens, G.; Riel, C.B.M.V.; Rekom, J.V. The CSR-quality trade-off: When can corporate social responsibility and corporate ability compensate each other? J. Bus. Ethics 2007, 74, 233-252.

39. Jensen, M.C. Value maximization, stakeholder theory, and the corporate objective function. Bus. Ethics Q. 2002, 12, 235-256.

40. Cai, Y.; Jo, H.; Pan, C. Doing well while doing bad? CSR in controversial industry sectors. J. Bus. Ethics 2012, 108, 467-480.

41. Wagner, T.; Lutz, R.J.; Weitz, B.A. Corporate hypocrisy: Overcoming the threat of incosistent corporate social responsibility perceptions. J. Mark. 2009, 73, 77-91.

42. Preston, L.E.; O'Bannon, D.P. The corporate social-financial performance relationship. Bus. Soc. 1997, 36, 419-429.

43. Groza, M.D.; Pronschinske, M.R.; Walker, M. Perceived organizational motives and consumer responses to proactive and reactive CSR. J. Bus. Ethics 2011, 102, 639-652.

44. Ethiraj, S.K.; Kale, P.; Krishnan, M.S.; Singh, J.V. Where do capabilities come from and how do they matter? A study in the software services industry. Strateg. Manag. J. 2005, 26, 25-45.

45. Haas, M.R.; Hansen, M.T. When using knowledge can hurt performance: The value of organizational capabilities in a management consulting company. Strateg. Manag. J. 2005, 26, 124.

46. Brooking, A. Intellectual Capital; International Thompson Business Press: London, UK, 1996.

47. Stewart, T. Intellectual Capital: The New Wealth of Organizations; Nicholas Brealey Publishing, Business Digest: New York, NY, USA, 1997.

48. Edvinsson, L.; Malone, M.S. Intellectual Capital: Realizing Your Company's True Value by Finding Its Hidden Brainpower; Collins: New York, NY, USA, 1997.

49. Zeghal, D.; Maaloul, A. Analyzing value added as an indicator of intellectual capital and its consequences on company performance. J. Intell. Cap. 2010, 11, 39-60.

50. Dzinkowski, R. The measurement and management of intellectual capital: An introduction. Manag. Account. (Br.) 2000, 78, 32-36.

51. Bontis, N. Assessing knowledge assets: A review of the models used to measure intellectual capital. Int. J. Manag. Rev. 2001, 3, 41-60.

52. King, A.W.; Zeithaml, C.P. Measuring organizational knowledge: A conceptual and methodological framework. Strateg. Manag. J. 2003, 24, 763-772.

53. Cormier, D.; Magnan, M. Environmental reporting management: A continental european perspective. J. Account. Public Policy 2003, 22, 43-62.

54. Cormier, D.; Magnan, M.; van Velthoven, B. Environmental disclosure quality: Do firms respond to economic incentives, public pressures or institutional conditions. Eur. Account. Rev. 2005, 14, 1-37. 
55. Harte, G.; Owen, D. Environmental disclosure in the annual reports of british companies: A research note. Account. Audit. Account. J. 1991, 4, 51-61.

56. Bowen, F.E. Environmental visibility: A trigger of green organizational response? Bus. Strategy Environ. 2000, 9, 92-107.

57. Hoffman, A.J. Institutional evolution and change: Environmentalism and the US chemical industry. Acad. Manag. J. 1999, 42, 351-371.

58. Saiia, D.H.; Carroll, A.B.; Buchholtz, A.K. Philanthropy as strategy when corporate charity "begins at home". Bus. Soc. 2003, 42, 169-201.

59. Chen, M.C.; Cheng, S.J.; Hwang, Y. An empirical investigation of the relationship between intellectual capital and firms' market value and financial performance. J. Intell. Cap. 2005, 6, 159-176.

60. Firer, S.; Williams, S.M. Intellectual capital and traditional measures of corporate performance. J. Intell. Cap. 2003, 4, 348-360.

61. Tan, H.P.; Plowman, D.; Hancock, P. Intellectual capital and financial returns of companies. J. Intell. Cap. 2007, 8, 76-95.

62. Chen, J.; Zhu, Z.; Xie, H.Y. Measuring intellectual capital: A new model and empirical study. J. Intell. Cap. 2004, 5, 195-212.

63. Hitt, M.A.; Ireland, R.D.; Hoskisson, R.E. Strategic Management: Competitiveness and Globalization; South-Western Pubishing Company: Cincinnati, OH, USA, 2001.

64. Carmeli, A.; Tishler, A. The relationships between intangible organizational elements and organizational performance. Strateg. Manag. J. 2004, 25, 1257-1278.

65. Sen, S.; Bhattacharya, C.B. Does doing good always lead to doing better? Consumer reactions to corporate social responsibility. J. Mark. Res. 2001, 38, 225-243.

66. Bertels, S.; Peloza, J. Running just to stand still? Managing CSR reputation in an era of ratcheting expectations. Corpor. Reput. Rev. 2008, 11, 56-72.

67. Clarkson, P.M.; Li, Y.; Richardson, G.D.; Vasvari, F.P. Revisiting the relationship between environmental performance and environmental disclosure: An empirical analysis. Account. Organ. Soc. 2008, 33, 303-327.

68. Plumlee, M.; Brown, D.; Marshall, R. Voluntary Environmental Disclosure Quality and Firm Value: Roles of Venue and Industry Type. J. Account. Public Policy 2010, 12, 1-43.

69. Berman, S.L.; Wicks, A.C.; Kotha, S.; Jones, T.M. Does stakeholder orientation matter? The relationship between stakeholder management models and firm financial performance. Acad. Manag. J. 1999, 42, 488-506.

70. Harrison, J.S.; Freeman, R.E. Stakeholders, social responsibility, and performance: Empirical evidence and theoretical perspectives. Acad. Manag. J. 1999, 42, 479-485.

71. Stanwick, P.A.; Stanwick, S.D. The relationship between corporate social performance, and organizational size, financial performance, and environmental performance: An empirical examination. J. Bus. Ethics 1998, 17, 195-204.

72. Prior, D.; Surroca, J.; Tribó, J.A. Are socially responsible managers really ethical? Exploring the relationship between earnings management and corporate social responsibility. Corpor. Gov. 2008, 16, 160-177.

73. Pulic, A. Intellectual capital-does it create or destroy value? Measur. Bus. Excell. 2004, 8, 62-68. 
74. Wang, W.Y.; Chang, C. Intellectual capital and performance in causal models: Evidence from the information technology industry in taiwan. J. Intell. Cap. 2005, 6, 222-236.

75. Nazari, J.A.; Herremans, I.M. Extended VAIC model: Measuring intellectual capital components. J. Intell. Cap. 2007, 8, 595-609.

76. Williams, S.M. Is intellectual capital performance and disclosure practices related? J. Intell. Cap. 2001, 2, 192-203.

77. Moore, G. Corporate social and financial performance: An investigation in the UK supermarket industry. J. Bus. Ethics 2001, 34, 299-315.

78. Bansal, P.; Clelland, I. Talking trash: Legitimacy, impression management, and unsystematic risk in the context of the natural environment. Acad. Manag. J. 2004, 47, 93-103.

79. Sealy, I.; Wehrmeyer, W.; France, C.; Leach, M. Sustainable development management systems in global business organizations. Manag. Res. Rev. 2010, 33, 1083-1096.

80. Polosky, M.; Zeffane, R. Corporate environmental commitment in Australia: A sectorial comparison. Bus. Strategy Environ. 1992, 2, 25-39.

81. World Commission on Environmental and Development (WCED). Our Common Future; Oxford Univerity Press: Oxford, UK, 1987.

82. Willums, J.O.; Goluke, U. From Ideas to Action: Busi ness and Sustainable Development ; Ad Notam Gyldendal: Oslo, Norway, 1992.

83. Acquaah, M.; Chi, T. A longitudinal analysis of the impact of firm resources and industry characteristics on firm-specific profitability. J. Manag. Gove. 2007, 11, 179-213.

84. Silverman, B.S. Technological resources and the direction of corporate diversification: Toward an integration of the resource-based view and transaction cost economics. Manag. Sci. 1999, 45, 1109-1124.

85. Baron, R.M.; Kenny, D.A. The moderator-mediator variable distinction in social psychological research: Conceptual, strategic, and statistical considerations. J. Personal. Soc. Psychol. 1986, 51, 1173-1182.

86. Kutner, M.H.; Nachtsheim, C.J.; Neter, J. Applied Linear Regression Models, 4th ed.; Mc Graw Hill: New York, NY, USA, 2008.

87. Venkatraman, N. The concept of fit in strategy research: Toward verbal and statistical correspondence. Acad. Manag. Rev. 1989, 14, 423-444.

(C) 2015 by the authors; licensee MDPI, Basel, Switzerland. This article is an open access article distributed under the terms and conditions of the Creative Commons Attribution license (http://creativecommons.org/licenses/by/4.0/). 